\title{
Promotion of HepG2 cell apoptosis by flower of Allium atroviolaceum and the mechanism of action
}

S. Khazaei ${ }^{1}$, R. Abdul Hamid ${ }^{1}$, N. Mohd Esa², V. Ramachandran ${ }^{3}$, Ghomi Tabatabaee F. Aalam ${ }^{1}$, A. Etemad and P. Ismail $\left.\right|^{1 *}$

\begin{abstract}
Background: Liver cancer is a high incidence and fatal disease, the fifth most frequent cancer worldwide that is usually diagnosed at an advanced stage. The number of deaths from liver cancer has not declined even following various therapies. Plant secondary metabolites and their semi-synthetic derivatives play a principal role in anticancer drug therapy, since they are effective in the treatment of specific characteristics while also reducing side effects. Allium atroviolaceum, a plant of the genus Allium has been used in folk medicine to protect against several diseases. However, cytotoxicity and the anti-proliferative effect of Allium atroviolaceum remain unclear. This work aims to investigate the anticancer properties of Allium atroviolaceum and the mechanism of action.
\end{abstract}

Methods: To evaluate the in vitro cytotoxicity of flower of Allium atroviolaceum, methanol extract at a dose range from 100 to $3.12 \mu \mathrm{g} / \mathrm{ml}$ was assessed against the HepG2 hepatocarcinoma cell line, and also on normal $3 T 3$ cells, by monitoring proliferation using the MTT assay method. A microscopy study was undertaken to observe morphological changes of HepG2 cells after treatment and cell cycle arrest and apoptosis were studied using flow cytometry. The apoptosis mechanism of action was assessed by the level of caspase-3 activity and expression of apoptosis related genes, $B c-2, C d k 1$ and $p 53$. The combination effect of the methanolic extract with doxorubicin was also investigated by determination of a combination index.

Results: The results demonstrated growth inhibition of cells in both dose- and time-dependent manners, while no cytotoxic effect on normal cell 3T3 was found. The results revealed the occurrence of apoptosis, illustrated by sub-G0 cell cycle arrest, the change in morphological feature and annexin- $V$ and propidium iodide staining, which is correlated with BCl-2 downregulation and caspase-3 activity, but p53-independent. In addition, a combination of Allium atroviolaceum and doxorubicin led to a significant synergistic effect.

Conclusion: These findings suggest that Allium atroviolaceum flower extract has potential as a potent cytotoxic agent against HepG2 cell lines, as it has commendable anti-proliferative activities against human hepatocarcinoma and it can be considered as an effective adjuvant therapeutic agent after the clinical trials.

Keywords: Allium atroviolaceum, HepG2, Apoptosis

\footnotetext{
* Correspondence: patimahismail@gmail.com

${ }^{1}$ Department of Biomedical Science, Faculty of Medicine and Health

Sciences, Universiti Putra Malaysia, Serdang, Selangor 43400, Malaysia

Full list of author information is available at the end of the article
} 


\section{Background}

Cancer, as a complex disease that results from genetic and epigenetic modifications of tumour suppressor genes or oncogenes, can be developed because of alterations of apoptosis-signalling pathways. Breakdown of the apoptosis process is observed in many human tumours, which may lead to transformation of a normal cell to a tumour cell [1]. Apoptosis is one of the primary targets for most conventional anti-cancer drugs. The drugs are able to induce fatal intracellular damage, which often activates a downstream cascade of molecular events [2]. Hepatocellular carcinoma (HCC) is a high incidence and fatal disease that is usually diagnosed at an advanced stage [3], the fifth most frequent cancer worldwide [4] and the third most fatal cancer [5]. In 2008, 748,000 liver cancer cases and 696,000 mortalities were estimated worldwide [6]. In Asian regions, HCC is the second most mortal cancer [7] with a peak incidence in East Asia [8]. Despite recent scientific advancement in hepatology, liver problems continue to increase [9]. There is no beneficial cure for this malignancy [10] and the recovery rate of $\mathrm{HCC}$ is low in most cases [11]. In addition, the inevitable side effects, such as toxicity to normal cells and bone marrow illustrate an instant demand to search for better methods and novel anti-cancer agents that would decrease the mortality rate of HCC with fewer side effects [12].

Natural products or their derivatives and synthetic pharmaceuticals based on natural product models are defined as natural origin [13] and play a principal role in anti-cancer drug therapy [14]. Natural products as medicines are effective in the treatment of specific characteristics while also reducing side effects [15]. Taken together, research in the field of natural products is in high demand to help humans overcome many newly emerging and known diseases, particularly cancers.

Allium atroviolaceum (A. atroviolaceum) is one of the lesser known species of Allium. The medicinal potency of the species of the Allium genus indicates tumour inhibitory effects at several stages of carcinogenesis, resulting from the high content of flavonols and organosulfur compounds; however, the mechanisms of action remain unclear [16]. Study of some species of Allium revealed different levels of anti-growth activity on the cancer cell lines; and minor cytotoxicity against the normal cell line [17] which makes this genus valuable for anticancer study.

The pharmaceutical value of $A$. atroviolaceum remains undiscovered. However, analysis of a flower extract has led to the isolation of a new sapogenin, named atroviolacegenin, a rare feature among sapogenins and saponins [18]. Saponins are natural glycosides which possess a wide range of pharmacological properties including cytotoxic activity [19]. Moreover, an investigation of the A. atroviolaceum chemical composition revealed a significantly high percentage of phenolic and organosulfur compounds [20]. Nowadays, inhibition of cancer cell growth by biosulfur compounds derived from Alliums has been the topic of intense research. They are efficient to alter carcinogen metabolism [21]. Study of the anticancer effect of A. atroviolaceum and understanding of its effects at a molecular level may lead to an effective cancer treatment and a promising approach to control of cancer.

In the current study, we hypothesize that flower extract of $A$. atroviolaceum exhibits cytotoxic activity against liver tumour cells, including a selective cytostatic effect that potentiates use as an anti-cancer drug. Furthermore, the extract may contain multiple bioactive compounds that could work alone or in combination to restrict cell survival.

\section{Methods}

\section{Plant material}

The plant sample was collected from Mazandaran, Iran in June, 2013. The plant sample was identified by Dr. Bahman Eslami (Assistant Professor of Plant Systems, Islamic Azad University of Ghaemshahr, Iran); the voucher specimens were deposited in Islamic Azad University of Ghaemshahr, Iran (No 720-722). Fresh flower of $A$. atroviolaceum (FAA) was collected, washed and air dried at room temperature. The dried material was homogenized to obtain a coarse powder and stored in airtight bottles. Approximately $5 \mathrm{gm}$ of the powdered material was subjected to soxhlet (Electrothermal Eng., Rochford, UK) extraction using $150 \mathrm{ml} \mathrm{70 \%} \mathrm{methanol.} \mathrm{The} \mathrm{extract} \mathrm{was}$ concentrated under reduced pressure by rotary evaporator (Büchi Labortechnik AG, Flawil, Switzerland) and solidified by freeze drier (SP Scientific, NY, USA) [22]. The dry residue of methanol extract was dissolved in dimethyl sulfoxide (DMSO) (Sigma-Aldrich, MO, USA) to obtain the stock solution $(1000 \mu \mathrm{g} / \mathrm{ml})$.

\section{Cell culture}

Human hepatoma HepG2 cells and mouse normal embryo cells (3T3) were obtained from the American Type Culture Collection (VA, USA). The cells were grown in RPMI-1640 supplemented with $10 \%$ FBS and $100 \mathrm{IU} / \mathrm{ml}$ penicillin streptomycin. The cultures were maintained at $37{ }^{\circ} \mathrm{C}$ in a humidified atmosphere of $5 \% \mathrm{CO}_{2}$.

\section{MTT Cytotoxicity assay}

HepG2 and normal 3 T3 cells were seeded at a density of $1 \times 10^{6} /$ well into 96-well culture plates, and incubated overnight before being exposed to various concentrations of FAA extract $(100,50,25,12.5,6.25$ and $3.12 \mu \mathrm{g} / \mathrm{ml})$. Doxorubicin was used as the positive control and untreated media was the negative control. After 24, 48 and $72 \mathrm{~h}, 20 \mathrm{ug} / \mathrm{ml}$ of MTT solution was added to each well and incubated for $4 \mathrm{~h}$. Each time course study was repeated at least three times. After addition 
of $100 \mu \mathrm{l}$ of DMSO, the absorbance was measured with an ELISA reader (BMG Labtech, Ortenberg, Germany) at a test wavelength of $540 \mathrm{~nm}$ and a reference wavelength of $690 \mathrm{~nm}$. The absorbance of the treated and control cells were used to determine the cytotoxicity of extract according to the following formula:

Cytotoxicity $(\%)=$ Absorbance of treated cells/absorbance of negative control $\times 100$ [23].

\section{Microscopic examination}

HepG2 cells were cultured into a six-well plate $\left(1 \times 10^{6}\right.$ cell $/ \mathrm{ml}$ ) and after being treated with $\mathrm{IC}_{50}$ concentration of FAA, morphological apoptotic changes were examined after 24, 48 and $72 \mathrm{~h}$ incubation and photographed using a phase-contrast microscope (Olympus Corporation, Tokyo, Japan) [24].

Acridine orange/propidium iodide (AO/PI) double staining Acridine orange/propidium iodide (AO/PI) double staining was used to observe the changes of apoptotic cell nuclei. When $\mathrm{AO}$ passes through the complete cell membrane, the nuclear DNA appears in green fluorescence while PI emits a red-orange fluorescence in the nuclear DNA of damaged cells [25]. The cells were seeded at a density of $1 \times 10^{6}$ cells per well of six-well plate and after incubation for $24 \mathrm{~h}$, the old media were replaced with the media treated with $\mathrm{IC}_{50}$ of FAA. After 24, 48 and $72 \mathrm{~h}$, the cells were washed with PBS. The mixture of $10 \mu \mathrm{g} / \mathrm{ml}$ acridine orange and $10 \mu \mathrm{g} / \mathrm{ml}$ propidium iodide (dissolved in PBS) was added to HepG2treated cells and then immediately observed under Leica fluorescence microscope DM 2500 (Leica Microsystem, Wetzlar, Germany) with 100x magnification. Images were captured using an Alpha Imager (AlphaInnotech, CA, USA). Each experiment was assayed three times $(n=3)$ [26].

\section{Cell cycle analysis}

Cell cycle analysis was carried out using a flow cytometer. Briefly, after plating $1 \times 10^{6}$ cells on a $25 \mathrm{~cm}^{2}$ culture flask for $24 \mathrm{~h}$, cells were incubated with the concentration of FAA that induced 25, 50 and $75 \%$ growth inhibition $\left(\mathrm{IC}_{25}, \mathrm{IC}_{50}\right.$ and $\left.\mathrm{IC}_{75}\right)$ for 24,48 and $72 \mathrm{~h}$. Thereafter, cells were trypsinized, centrifuged at $1000 \mathrm{rpm}$ for 10 minutes, washed with PBS and fixed with $70 \%$ ethanol overnight at $20{ }^{\circ} \mathrm{C}$. The fixed cells were washed with PBS and incubated with $500 \mu \mathrm{PI} / \mathrm{RNase}$ (400 $\mu \mathrm{l}$ propidium iodide and $100 \mu \mathrm{l}$ ribonuclease A). Stained cells were incubated at room temperature in the dark for $30 \mathrm{~min}$ before analysis. Cell-cycle distribution was then analysed by flow cytometry using the $\mathrm{BD}$ LSRFortessa $^{\text {Tix }}$ Cell Analyzer (Becton Dickinson, NJ, USA). The cell cycle distribution of 10,000 cells was recorded and the percentage of cells at G0/G1, S, and G2/M phases was analysed with BD FACSDiva ${ }^{\text {Twt }}$ software [27].
Flow cytometric analysis of apoptosis using Annexin V An annexin $\mathrm{V}$ apoptosis detection kit for flow cytometry (Sigma-Aldrich, MO, USA) was used. The annexin V assay was carried out in conjunction with PI staining. HepG2 cells were cultured for $24 \mathrm{~h}$ in a $25 \mathrm{~cm}^{2}$ culture flask $\left(1 \times 10^{6}\right.$ cells/well $)$ in the presence of different concentrations of the extract $\left(\mathrm{IC}_{25}, \mathrm{IC}_{50}\right.$ and $\left.\mathrm{IC}_{75}\right)$. After 24, 48 and $72 \mathrm{~h}$, cells were harvested by trypsinization and centrifugation at $1000 \mathrm{rpm}$ for $5 \mathrm{~min}$ and then re-suspended in $1 \mathrm{x}$ binding buffer prior to staining with $5 \mu \mathrm{l}$ of annexin $\mathrm{V}$ and $10 \mu \mathrm{l}$ of propidium iodide solution for $10 \mathrm{~min}$ at room temperature. FACS analysis was then carried out according to the manufacturer's instructions, using a BD LSRFortessa ${ }^{\mathrm{Tm}}$ Cell Analyzer (Becton Dickinson, NJ, USA). About 10,000 counts were recorded in each analysis [28].

\section{Caspase-3 colorimetric assay}

A caspase colorimetric assay kit (Biovision, CA, USA) was used to measure the caspase -3 activity in treated cell line according to manufacturer's instructions. The cells $\left(10^{6} / \mathrm{ml}\right)$ were placed in a six-well plate for $24 \mathrm{~h}$ before treatment with various concentrations of FAA. After 24, 48 and $72 \mathrm{~h}$, treated cells were collected into micro-centrifuge tubes and centrifuged at $1000 \mathrm{rpm}$ for 5 min. Following two washes of pelleted cells with PBS, lysis buffer $(50 \mu \mathrm{l})$ was added and mixed well. The cells were then incubated on ice for $10 \mathrm{~min}$ and subjected to centrifugation at $10,000 \mathrm{rpm}$ for $1 \mathrm{~min}$. Supernatants $(50 \mu \mathrm{l})$ were transferred into wells of a 96-well plate; $50 \mathrm{ml}$ of $2 \times$ reaction buffer containing $0.5 \mu \mathrm{l}$ DTT and $5 \mathrm{ml}$ of caspases substrate was added to each sample. Samples were then incubated at $37{ }^{\circ} \mathrm{C}$ for $2 \mathrm{~h}$ in the dark. The cleavage of labelled substrate pNA into chromo-phore p-nitroanilide (pNA) was determined by measuring the absorbance (optical density, OD) at $405 \mathrm{~nm}$ using a FLUOstar Omega microplate reader (BMG Labtech, Ortenberg, Germany). The result of the induced group's caspases activity was obtained by computing OD inducer/OD negative control with the background OD values from cell lysates and buffers subtracted [23].

\section{Quantitative polymerase chain reaction (qPCR)}

To examine the expression of the target genes in HepG2 cell lines, RNA extraction including DNase treatment was carried out by RNeasy mini kit (Qiagen Inc., CA, USA), according to the manufacturers protocol. RNA concentration was measured using a Thermo Scientific NanoDrop $^{\mathrm{Tm}} 1000$ Spectrophotometer along with its analytical software V3.7 (Thermo Fisher Scientific, DE, USA), RNA samples without indication of degradation were further assessed on a Bioanalyzer (Agilent 2100 Bioanalyzer $^{\text {rm }}$ system-Agilent Technologies, Waldbronn, 
Germany). Total RNA $(1 \mu \mathrm{l})$ was reverse-transcribed using an RT2 first strand kit (Qiagen Inc., CA, USA). Quantitative PCR was performed on reference and target genes. The gene primer ( $\mathrm{RT}^{2} \mathrm{qPCR}$ Primer Assays, Qiagen Inc., CA, USA) sequences were selected based on previous databases and on publications reporting stable gene expression profiles. The respective forward and reverse primers are as follows: $B c l-2$ : 5'TAC CTG AAC CGG CAC CTG-3' and 5'- GCC GTA CAG TTC CAC AAA GG-3'; Cdk1: 5'- GGGTCAGCTCGCTACTCAA C-3' and 5'-AAGTTTTTGACGTGGGATGC-3'; p53: 5'TGT GGA GTA TTT GGA TGA CA-3' and 5'- GAA CAT GAG TTT TTT ATG GC-3'; GAPDH: 5-TCCTG CACCA CCAACTGCTTAG-3' and 5'- GGCATGGAC TGTGG TCATGAGT-3'.

A sample without cDNA template (ntc) was used as the negative control. qPCR was performed on the Corbett Rotor-Gene 6000 (Qiagen Inc., CA, USA). RNase/DNase-free water $(10.5 \mu \mathrm{L}), \mathrm{RT} 2 \mathrm{SYBR}^{\circ}$ green master mix $(12.5 \mu \mathrm{L})$, assay primer $(1 \mu \mathrm{L})$ and cDNA template was mixed to a final volume of $25 \mu \mathrm{l}$ and run at $95{ }^{\circ} \mathrm{C}$ for 10 minutes to activate the enzyme, 40 cycles of 15 seconds at $95^{\circ} \mathrm{C}$ (denaturation) followed by $30 \mathrm{sec}-$ onds at $60{ }^{\circ} \mathrm{C}$ (annealing and synthesis). The Ct cycle was used to determine the expression level of control and FAA treated cells. The gene expression level was then calculated by the following formula:

$$
2^{\Delta \Delta \mathrm{Ct}}=2^{\mathrm{Ct}(\text { treated cells) }-\mathrm{Ct} \text { (control cells) }}[29] \text {. }
$$

\section{Determination of combination index}

HepG2 cells were seeded at $10^{6}$ cells per ml, allowed to attach overnight and treated with the FAA, doxorubicin or their combination for 24,48 and $72 \mathrm{~h}$ at $37^{\circ} \mathrm{C}$. The cytotoxic effect was determined using MTT assay. The $\mathrm{IC}_{50}$ obtained for single-agents were compared to the $\mathrm{IC}_{50}$ calculated for each cytotoxic agent after combination of two drugs. The combined effect of FAA and doxorubicin was then analysed using the CompuSyn software in different concentrations. All the tests were performed in triplicate. The $\mathrm{CI}$ value $<1,=1$ and $>1$ represent the synergistic, additive and antagonistic effects, respectively [30].

\section{Statistical analysis}

The data were expressed as means $\pm \mathrm{SD}$, and significant differences were determined by one-way analysis of variance (ANOVA) followed by Duncan's multiple range tests and Student's $t$-test. A $p$-value of less than 0.05 was considered statistically significant.

\section{Results}

\section{Optimum dose of FAA extract to inhibit HepG2 cell} proliferation

The anti-proliferative activities of methanol extract from FAA illustrated an inhibition effect on the cell proliferation in a time and dose-dependent manner. HepG2 cells treated with FAA showed inhibited cell proliferation at $24 \mathrm{~h}$ with the $\mathrm{IC}_{50}$ value of $57.5 \pm 4.95 \mu \mathrm{g} / \mathrm{ml}$, which markedly decreased to $44 \mu \mathrm{g} / \mathrm{ml}$ at $48 \mathrm{~h}$ and $26.67 \pm 3.5 \mu \mathrm{g} / \mathrm{ml}$ at $72 \mathrm{~h}$ (Fig. 1a). Moreover, according to our previous study, doxorubicin was considerably more toxic against HepG2 cells whose $\mathrm{IC}_{50}$ was $4.75 \pm 0.6$ at $24 \mathrm{~h}$, which gradually decreased to $3.47 \pm 0.3$ at $48 \mathrm{~h}$ and $1.7 \pm 1$ at $72 \mathrm{~h}$ (Fig. 1c) [31]. However, doxorubicin's toxicity towards healthy mouse fibroblast cells, 3T3, was also considerably higher than FAA, which inhibits $50 \%$ cell viability at $6.45 \pm 1.3 \mu \mathrm{g} / \mathrm{ml}$ (Fig. 1d) while FAA showed selective cytotoxicity, as the $\mathrm{CC}_{50}$ of normal cell is $>100 \mu \mathrm{l}$ of FAA (Fig. 1b).

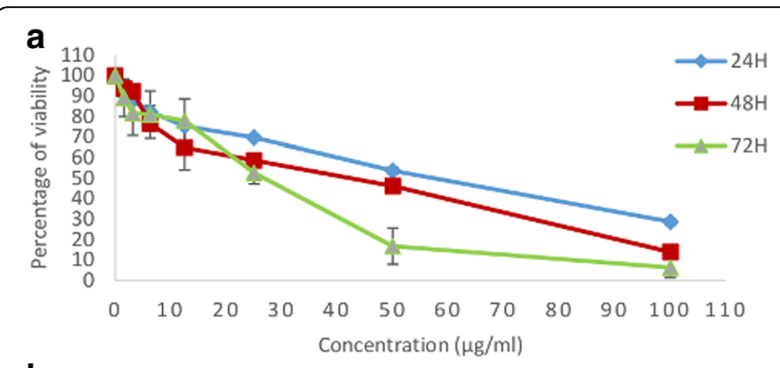

b

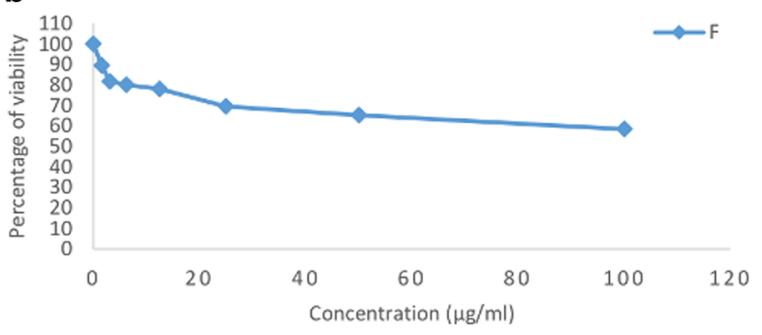

C
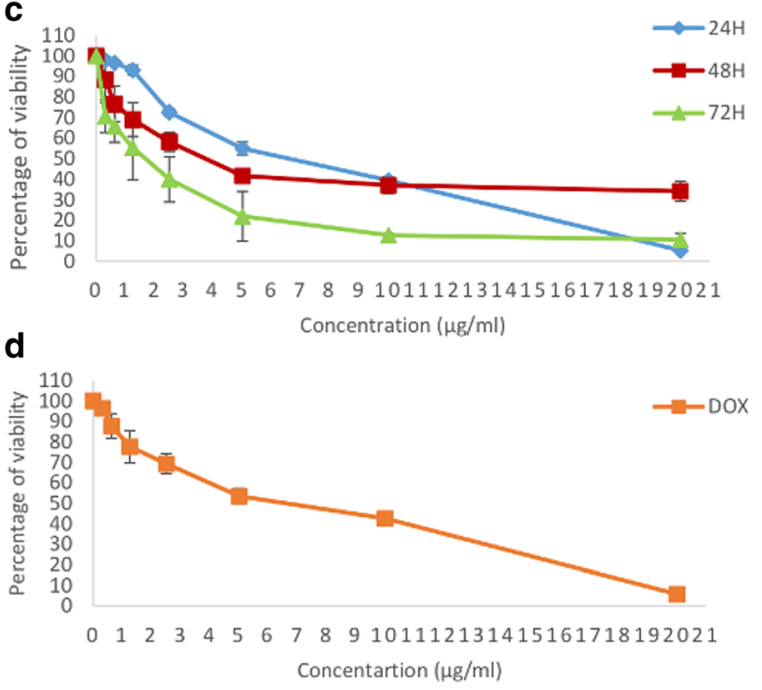

Fig. 1 Antiproliferatic activity of FAA and doxorubicin on HepG2 and normal $3 T 3$ cells. The effect of FAA on proliferation of (a) HepG2 and (b) $3 T 3$ cells and doxorubicin on proliferation of (c) HepG2 [31] and (d) $3 T 3$ cells. Values are means \pm SD of three independent experiments 


\section{Microscopic evaluation of morphological changes in HepG2 cells}

Morphological changes in the cells and the nuclei were observed under 40X magnification of the inverted phase contrast microscope, aided by AO/PI staining after treatment for 24, 48 and $72 \mathrm{~h}$. Phase contrast microscopy of the cells revealed the original morphological form of control cells, most of which were adherent to the surface, but the presence of floating or detachment of nonviable cells in a dose- and time-dependent manner. Exposure of the cancer cells to FAA led to cytoplasm condensation $(24 \mathrm{~h})$, shrinkage and formation of apoptotic bodies $(48 \mathrm{~h})$ and the formation of debris $(72 \mathrm{~h})$ that are classic morphologies of apoptosis [32]. There was a visible loss of contact and rounding of cell shape posttreatment as compared to the tightly packed and distinctively epithelial monolayer formation in the untreated cells, indicative of apoptosis (Fig. 2).

In order to aid the visualization, cells were stained with $\mathrm{AO} / \mathrm{PI}$ mixture and nuclear morphology changes were observed under the fluorescence microscope. The cells treated with FAA showed nuclear margination and chromatin condensation ( $24 \mathrm{~h})$, membrane blebbing $(48 \mathrm{~h})$, nuclear fragmentation and membrane loss $(72 \mathrm{~h})$. Cells stained with orange colour indicated loss of cell membrane integrity. Morphological damage was seen in cell lines when treated with FAA as compared to undamaged nuclei in untreated cells. The untreated cells were live and stained bright green (Fig. 3).

\section{Effect of FAA extract on cell cycle phase distribution}

Cell cycle distribution of FAA-treated cells in a concentration- and time-response manner was assessed by flow cytometry. Synchronized cells exposed to FAA indicated a noticeable enhancement in cell proportion in sub-G0 phase in a time- and dose-dependent manner. In addition, the cells treated with $\mathrm{IC}_{25}$ concentration of FAA showed a significant increase from $12.9 \%$ (in the control cells) to $15.56 \%$ in the $\mathrm{G} 2 / \mathrm{M}$ phase at $48 \mathrm{~h}$. These results indicate that the anti-proliferative effect of
FAA is not associated with cell cycle arrest, except in low concentration of FAA at $48 \mathrm{~h}$ where the antiproliferative effect might be related to an arrest in G2/M phase of the cell cycle (Fig. 4).

\section{FAA extract induces apoptosis in HepG2 cells}

Externalization of phosphatidylserine on the cell membrane is a distinctive feature of apoptotic cells. Annexin $\mathrm{V}$ is a recombinant protein which has a high affinity for this externalized moiety and can be used to detect apoptosis [33]. Apoptotic cell death was thus evaluated using annexin V-PI dual staining. Data analysis of HepG2 cell lines revealed that $\mathrm{IC}_{50}$ and $\mathrm{IC}_{75}$ values of FAA led to significant time- and dose-dependent reduction in the viable cell proportion. At $24 \mathrm{~h}$ of treatment, entering into the early apoptosis had sharply enhanced to $12.3 \%$ and $26.95 \%$ after treatment with $\mathrm{IC}_{50}$ and $\mathrm{IC}_{75}$ of FAA, compared to $3.2 \%$ in the control while the cell proportion present in late apoptosis was greatly raised to $1.25 \%$ by $\mathrm{IC}_{75}$ of FAA from $0.1 \%$ in the control. The cell percentage in necrosis stages after treatment with $\mathrm{IC}_{75}$ of FAA markedly increased to $0.5 \%$ from $0 \%$ in untreated cells. At $48 \mathrm{~h}$, the percentages of cells entering the early apoptosis stage were significantly higher after treatment with $\mathrm{IC}_{50}$ and $\mathrm{IC}_{75}$ of FAA (12.5\% and $\left.35 \%\right)$, when compared to untreated cells $(1.25 \%)$. Late apoptotic cell proportion also increased to $1.45 \%$ and $1.9 \%$ by $\mathrm{IC}_{50}$ and $\mathrm{IC}_{75}$ of FAA, compared to the untreated cells $(0.45 \%)$. No significant effect was recorded in the percentages of necrotic cells at $48 \mathrm{~h}$. In addition, $72 \mathrm{~h}$ treatment illustrated a dramatic increment in the percentage of early apoptotic cells treated with $\mathrm{IC}_{50}$ and $\mathrm{IC}_{75}$ of FAA $(27.35 \%, 12.75 \%)$, compared to the untreated cells (2.5\%). In contrast to 24 and $48 \mathrm{~h}$, at $72 \mathrm{~h}$, the percentage of late apoptotic cells was higher than early apoptosis, as late apoptotic cell percentage was dramatically enhanced by $\mathrm{IC}_{50}$ and $\mathrm{IC}_{75}$ of FAA (8.5\% and $\left.68.75 \%\right)$, compared with the untreated cells $(4.45 \%)$. In contrast, the percentage of necrotic cells with $\mathrm{IC}_{75}$ of FAA decreased to $0 \%$ from $5.4 \%$ in the untreated cells (Fig. 5).
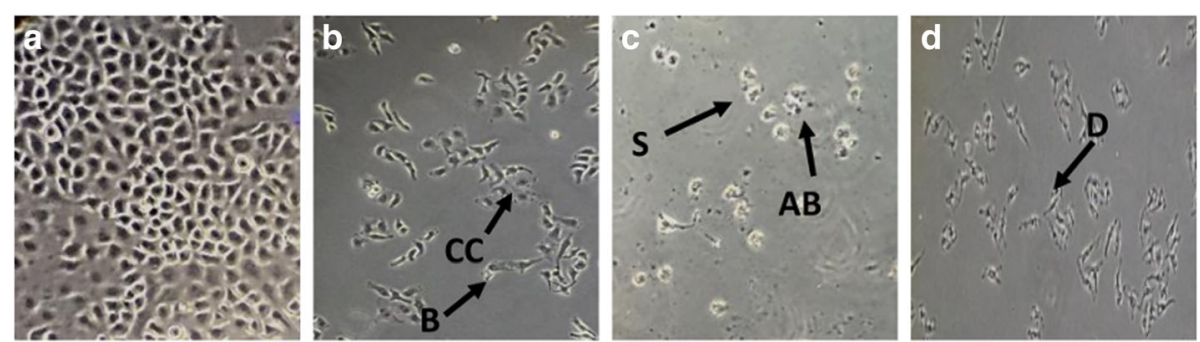

Fig. 2 Representative images to show morphological observation of HepG2 No treatment (a), treatment with FAA for $24 \mathrm{~h}(\mathbf{b}), 48 \mathrm{~h}$ (c), and $72 \mathrm{~h}$ (d) observed under inverted light microscopy (40X). Live cells (L), cytoplasm condensation (CC), blebbing (B), shrinkage (S), apoptotic bodies (AB) and debris (D). Similar cellular morphology was observed in three independent experiments $(n=3)$ 

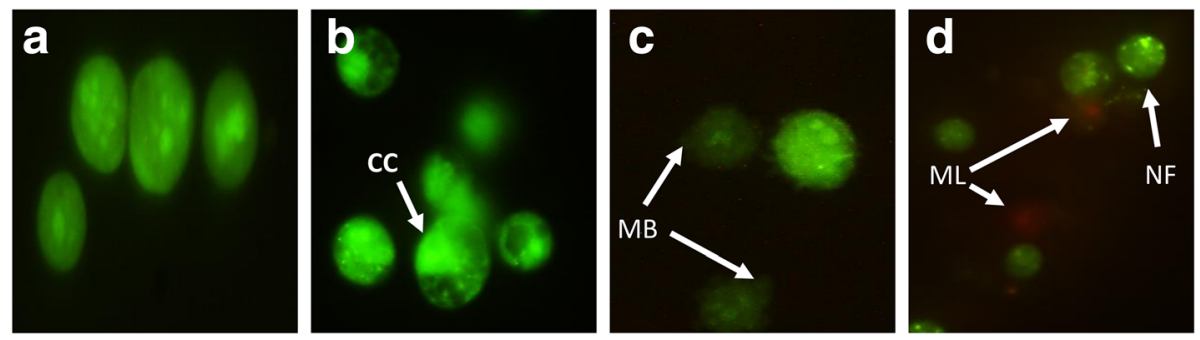

Fig. 3 Treated HepG2 stained with AO/PI observed under fluorescence microscope. Photographic documentation was carried out at 40x magnification. a Control (untreated) cells (b) Cell treated with FAA at $24 \mathrm{~h}$ (c) $48 \mathrm{~h}$ (d) $72 \mathrm{~h}$. Treated cells showed the typical characteristic of apoptosis such as nuclear margination (NM), chromatin condensation (CC), nuclear fragmentation (NF), membrane blebbing (MB), and membrane loss (ML)

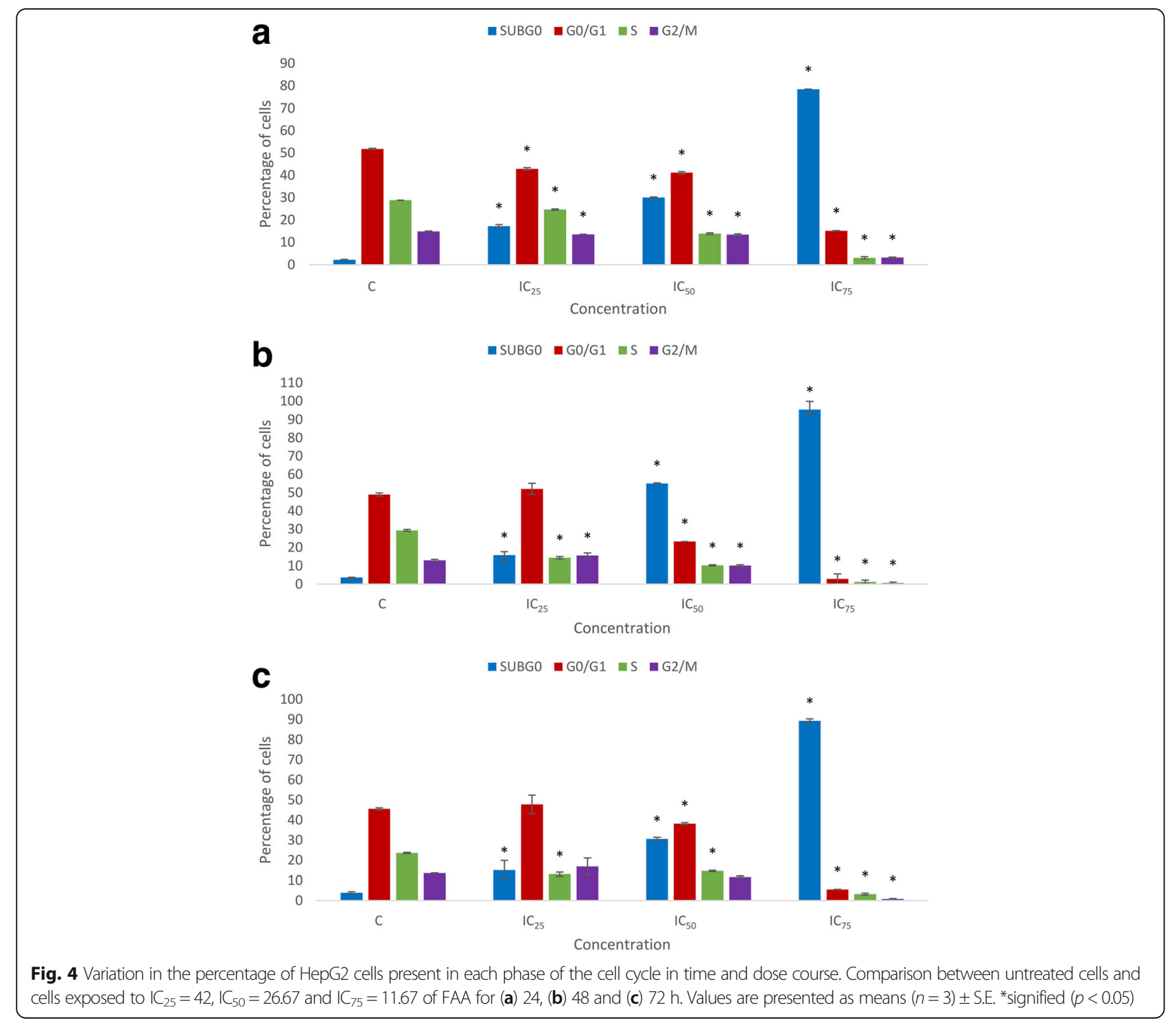



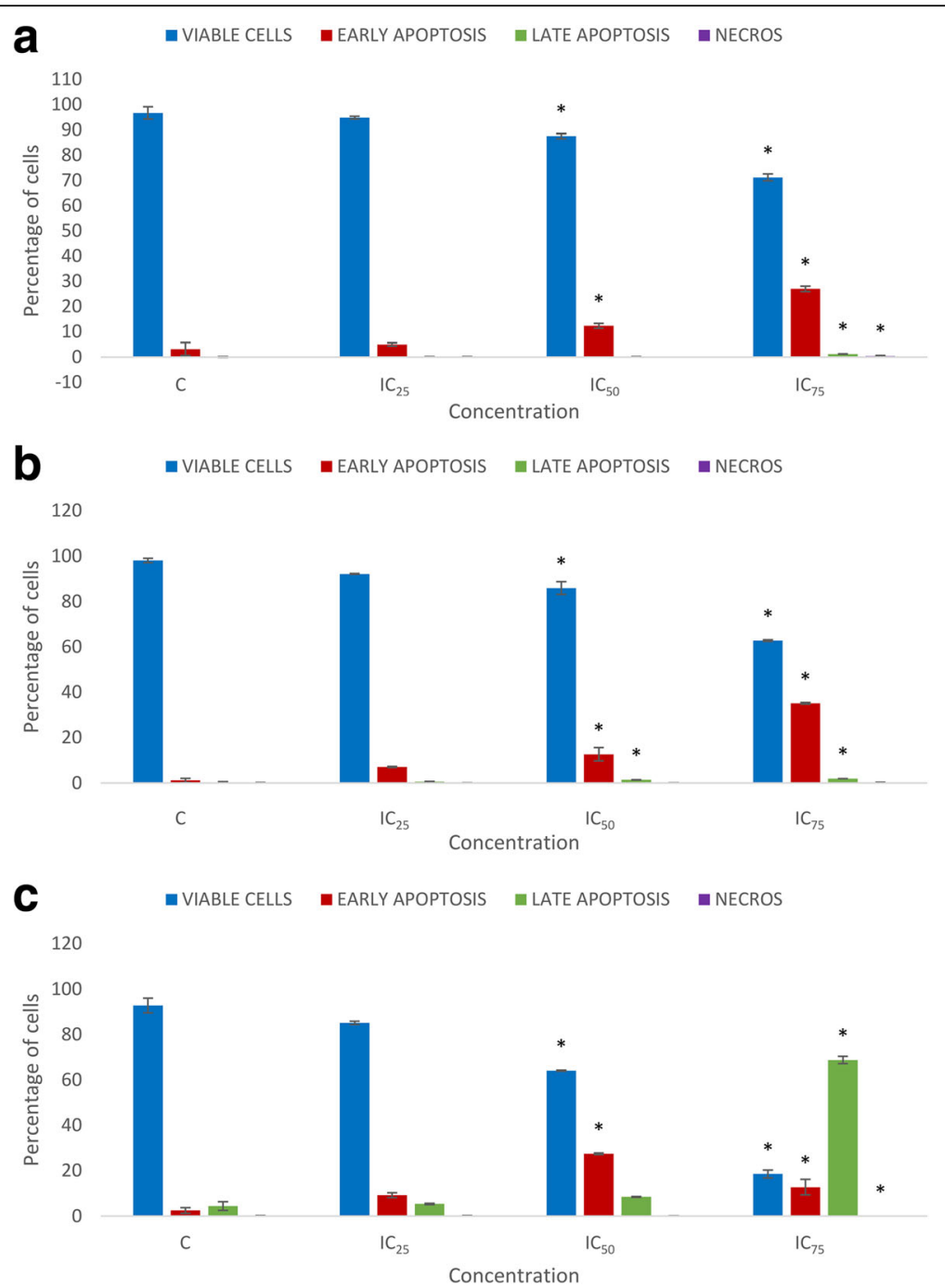

Fig. 5 Effect of FAA on the induction of apoptosis in HepG2 cells. The proportion of cells present in early apoptosis, late apoptosis and necrosis stage after treatment by $I C_{25}=42$, IC $50=26.67$ and $I C_{75}=11.67$ of FAA for (a) 24 , (b) 48 and (c) $72 \mathrm{~h}$. Values are presented as means $(n=3) \pm S . E$. *signified $(p<0.05)$ compare to the control

\section{Caspase-3 activity}

The activity of caspase-3, the terminal effector in the apoptotic cascade and the enzymatic major marker of apoptosis, was assessed in a time- and dose-course manner. In the treated HepG2, the caspase- 3 activity after $24 \mathrm{~h}$ increased only in $\mathrm{IC}_{50}$ of FAA. The increment reached a higher amount when the cells were treated with $\mathrm{IC}_{25}$ and $\mathrm{IC}_{50}$ of FAA at $48 \mathrm{~h}$. Interestingly, with the increase of exposure time with FAA, caspase-3 activity had an eminent increase in all concentrations at $72 \mathrm{~h}$ compared to those values in the cells that were treated for $24 \mathrm{~h}$ and $48 \mathrm{~h}$ (Fig. 6).

\section{Expression level of corresponding genes in HepG2 cells} The association between cell cycle and apoptosis related gene expression level in treated cells with the results obtained by proliferation and apoptosis tests were assessed by qPCR method. Evaluation of $\mathrm{Bcl}-2$, $C d k 1$ and $p 53$ expressions in FAA-treated HepG2 cells revealed alternative modulations in the level of expression. FAA treatment showed a slight (1.3-fold and 1.34-fold) downregulation of $\mathrm{Bcl}-2$ in $\mathrm{IC}_{25}$ and $\mathrm{IC}_{50}$ and a considerable (2.76 fold) downregulation in $\mathrm{IC}_{75}$. Regarding the expression levels of $C d k 1$, no significant alteration was found upon treatment with FAA, apart from a slight increase of marginal statistical significance after treatment with $\mathrm{IC}_{25}$ and $\mathrm{IC}_{50}$ by 1.02 - and 1.28 -fold. The $p 53$ was found to be downregulated after all three indicated concentrations of FAA, exhibiting a 1.69-, 2.26- and 3.94-fold decrease after treatment with $\mathrm{IC}_{25}, \mathrm{IC}_{50}$ and $\mathrm{IC}_{75}$ concentrations, respectively (Fig. 7). 


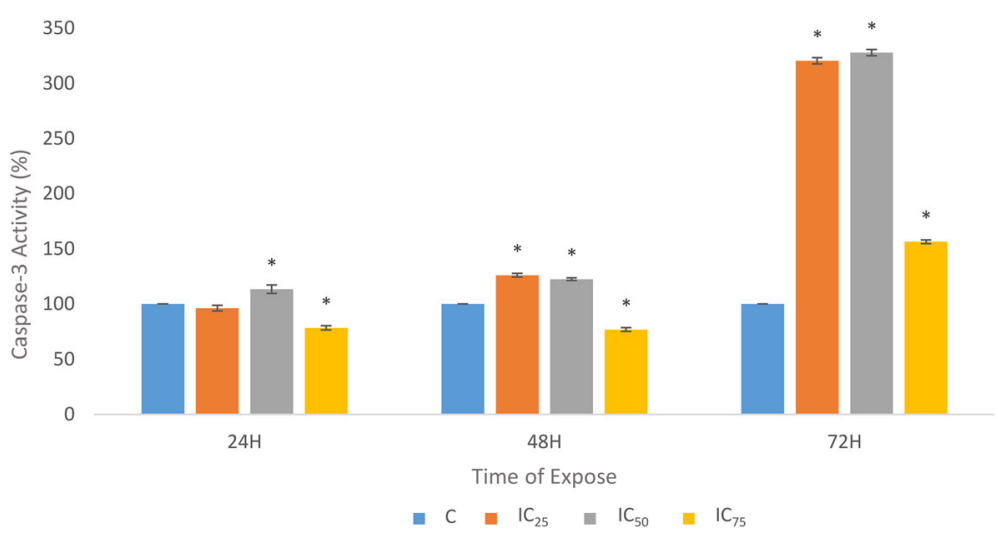

Fig. 6 Effect of FAA on executioner caspases-3 activity in HepG2 cells. The cells were treated with $I C_{25}=42, I C_{50}=26.67$ and $I C_{75}=11.67$ of $F A A 24,48$ and $72 \mathrm{~h}$ treatment. Results are expressed as the mean optical density $(405 \mathrm{~nm}) \pm$ SD of three independent experiments. The symbol * indicates significant difference from control $(p<0.05)$

\section{Synergistic effect}

In order to determine the FAA synergistic effect with doxorubicin, the concentrations of the extract and chemotherapeutic drug at their respective $\mathrm{IC}_{50}$ values against HepG2 cells were applied using an MTT assay. The mixture significantly inhibited the cell proliferation in a dose- and timedependent manner, compared to the results of single agents. The $\mathrm{IC}_{50}$ of doxorubicin decreased considerably to $1.77 \mu \mathrm{g} / \mathrm{ml}, 0.65 \mu \mathrm{g} / \mathrm{ml}$ and $0.32 \mu \mathrm{g} / \mathrm{ml}$ at 24,48 and $72 \mathrm{~h}$ (from 4.75, 3.47 and 1.7) (Fig. 8). Moreover, combination analysis was performed using the method described by Chou and Talalay through calculation of CI (combination index) [34], using CompuSyn software to assess the synergistic effect $(\mathrm{CI}<1)$, additive effect $(\mathrm{CI}=1)$, or antagonistic effect $(\mathrm{CI}>1)$. The $\mathrm{CI}$ value indicated a synergistic effect in all concentrations and time periods, except for $\mathrm{IC}_{75}$ at $24 \mathrm{~h}$ $(\mathrm{CI}=1.02$, additive $)$. The $\mathrm{CI}$ value showed an upward trend at $24 \mathrm{~h}(\mathrm{CI}=0.93,0.75,0.79,1.02)$ and $72 \mathrm{~h}(\mathrm{CI}=0.32,0.41$, $0.52,0.72)$, in $\mathrm{IC}_{12.5}, \mathrm{IC}_{25}, \mathrm{IC}_{50}$ and $\mathrm{IC}_{75}$, respectively, but a downward trend at $48 \mathrm{~h}(\mathrm{CI}=0.78,0.79,0.44,0.37)$. The results demonstrated that the growth of HepG2 was inhibited significantly when doxorubicin was combined with FAA, as opposed to a single-agent treatment (Fig. 9).

\section{Discussion}

Natural products and pharmaceutical compounds have been studied as cancer chemo-preventive agents, in vitro and in vivo [35]. There is limited information on the medicinal value of Allium atroviolaceum, particularly its cytotoxicity against cancer cells. Hence, the aim of the current study was evaluation of FAA extract potency on cell proliferation inhibition and inducing of apoptosis, which could contribute to a better understanding of the mechanisms of their potential carcinogenicity.

The present study demonstrated that FAA was an effective inhibitor against HepG2 cell proliferation, suggesting the presence of bioactive compounds in the extract [36]. However, the positive control, doxorubicin, showed a considerably stronger effect in comparison to FAA. Furthermore, the extract exhibited stronger cytotoxic activity after $72 \mathrm{~h}$ of exposure only at higher concentrations, whereas cytotoxic effects of lower concentrations were not significantly different from 24 and $48 \mathrm{~h}$. This result indicates that the cells could be killed immediately after treatment by low concentrations, but after a long time, the surviving cells were stimulated for proliferation, or cells had adapted to the treatment and were recovered while the high FAA dose inhibits the proliferation in time course. In reality, cancer cells that exhibit resistance at one concentration may indicate growth inhibition at higher doses of the same preparation [37]. In addition, the applicability of a substance as a pharmacological drug depends on the balance between its therapeutic and toxicological effects [38]. The results showed that the extracts did not produce a cytotoxic effect towards normal cells, suggesting that the anticancer activity of FAA might be specific to HepG2 cells, in contrast to doxorubicin which was toxic against normal cells.

The suppression of cancer cell growth may occur through interference with fundamental cellular functions including apoptosis [39]. The difference between cytotoxicity and apoptosis is demonstrated by a series of specific morphological features [40]. One of the best methods for apoptosis definition is microscopic observation of cell morphology [41]. The morphology of treated cells demonstrates a substantial amount of cells undergoing apoptosis. The changes in cell shape after $24 \mathrm{~h}$ were heralded by cytoplasm condensation together with blebbing. Apoptosis proceeded to a subsequent stage after $48 \mathrm{~h}$ characterized by a rounding of cells and the frequent protrusion of apoptotic bodies. Cell necrosis was observed at $72 \mathrm{~h}$, distinguished by initial cell swelling and bursting of both the endoplasmic reticulum and lysosomes. The latter of these two organelles contains digestive enzymes which contribute to further autolysis of the cell and its final disintegration. This releases cellular 

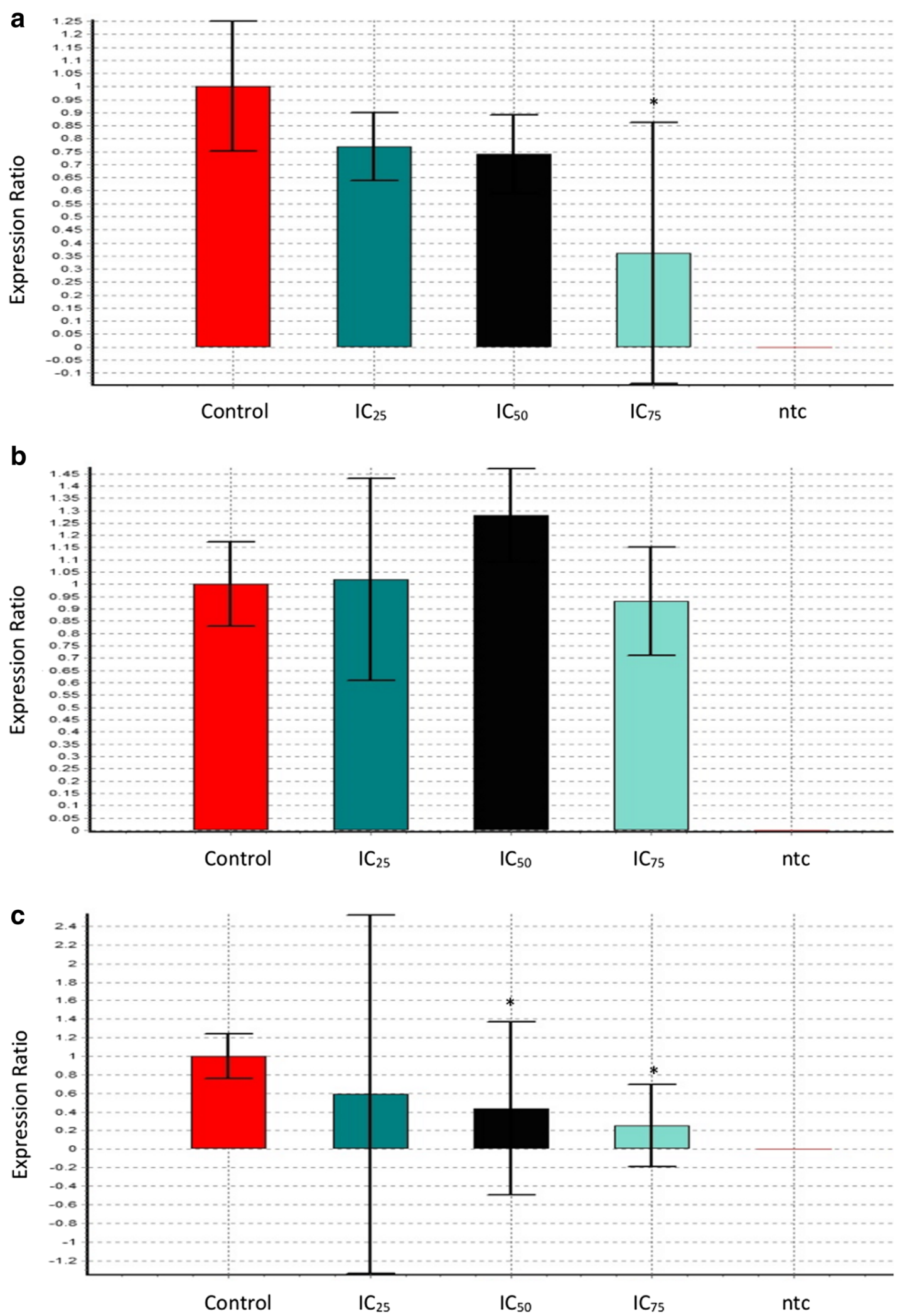

Fig. 7 (See legend on next page.) 
(See figure on previous page.)

Fig. 7 Real-time quantitative PCR analysis illustrates the gene expression in HepG2 cells. The relative quantification of the target gene, (a) $B C$-2, (b) $C d k 1$ and (c) $p 53$, by the delta-delta-Ct method was done using the Qiagen software after treatment with $I C_{25}=42, I C_{50}=26.67$ and $I C_{75}=11.67$ of FAA for $24 \mathrm{~h}$. A sample without cDNA template (ntc) was used as the negative control. Values are means \pm SD of three independent experiments

debris which elicits the inflammatory response that normally accompanies necrosis [42]. The results illustrated that apoptotic events may occur in different time courses that may depend on the inducing mechanism.

A comparison of nuclear morphology at these various stages by AO/PI stain using fluorescent microscopy suggested that the FAA treated HepG2 cells displayed nuclear morphological changes. Untreated cells were observed with a green intact nuclear structure whereby, early apoptosis is obvious by intercalated AO within the fragmented DNA. The features of early apoptotic death with nuclear chromatin condensation and margination were clearly observed at $24 \mathrm{~h}$. While blebbing was noticed as moderate apoptosis after $48 \mathrm{~h}$ treatment with FAA. Blebbing is a normal cellular activity observed during mitosis. In damaged cells, the presence of blebs illustrates impending cell death and apoptotic cells unable to stop blebbing and flatten back onto the substratum $[43,44]$. In addition, late stages of apoptosis were observed after $72 \mathrm{~h}$ treatment with FAA. Comparison of the nuclear and surface morphological changes indicated simultaneous events, regarding the time of active surface blebbing, shrinkage and formation of apoptotic bodies concomitant with nuclear margination during the early apoptotic process $(24 \mathrm{~h})$ and the formation of debris on the surface aligned with membrane permeability to PI in the necrosis process $(72 \mathrm{~h})$.

Based on the antiproliferative activity of FAA on HepG2 cells, the proportion of the cell in different phases of the cell cycle was analysed to determine the alteration of cell cycle phases, affected by FAA. The results exhibited a high proportion of cells at sub-G0 phase, because of nuclear DNA cleavage into multiple fragments [45], illustrating induced apoptosis cell death [46]. Controversially, the proportion of cells in the phase of G0/G1, S and G2/M (except $\mathrm{IC}_{25}$ of $48 \mathrm{~h}$ ) considerably decreased in a dosedependent manner compared to the control (Fig. 4). This result provided evidence that FAA induces apoptosis and, in turn, inhibits cell growth. Thus, apoptotic cell death of FAA was further analysed in HepG2 cells.

Apoptosis compared to necrosis is a desired somatic defence mechanism against cancer cells [41]. Annexin V/PI staining was performed producing a significant increase in the early- and late-apoptotic populations in various timeand dose-course in HepG2 cells. Annexin V- PI- considered as viable cells, while Annexin V+/PI- staining patterns showed early apoptotic cells; whereas Annexin V+/PI+ exhibited late apoptotic cells due to a loss of plasma membrane integrity [47] and VFITC-/PI+ was considered as necrotic cells [48]. In early apoptotic cells ( 24 and $48 \mathrm{~h}$ ) the membrane integrity is retained, which is aligned with our observation by inverted and fluorescent microscopy, while late apoptotic cells with compromised membranes performed for a longer time $(72 \mathrm{~h})$ in treated cells with high concentration $\left(\mathrm{IC}_{75}\right)$. This result demonstrated that entire time span for apoptosis, from early to the late apoptosis, is a very long process in HepG2 cells, exposed to FAA. It is worth noting that FAA did not promote necrosis at the times and dose tested in HepG2 cell line that showed relatively low percentages of annexin $\mathrm{V}-/ \mathrm{PI}+$ cells over dose and time course possibly because of the release of pro-inflammatory intracellular contents [49], while the microscopic observation showed PI stained cells, displaying occurrence of necrosis. Apparently the membrane non-permeability of apoptotic cells could be kept for macromolecules temporarily, even after they become permeable for small charged molecules like PI, therefore, the time required for their elimination can be extended [50].

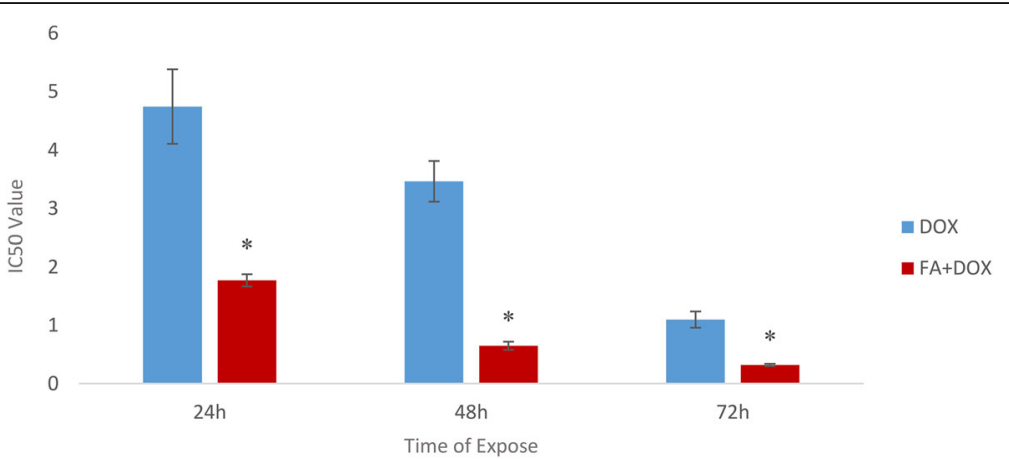

Fig. 8 Interaction between doxorubicin and FAA in human liver cancer cell (HepG2). Values are calculated from three independent experiments. ${ }^{*}=p<0.05$ compare the combination of doxorubicin-FAA and doxorubicin alone 


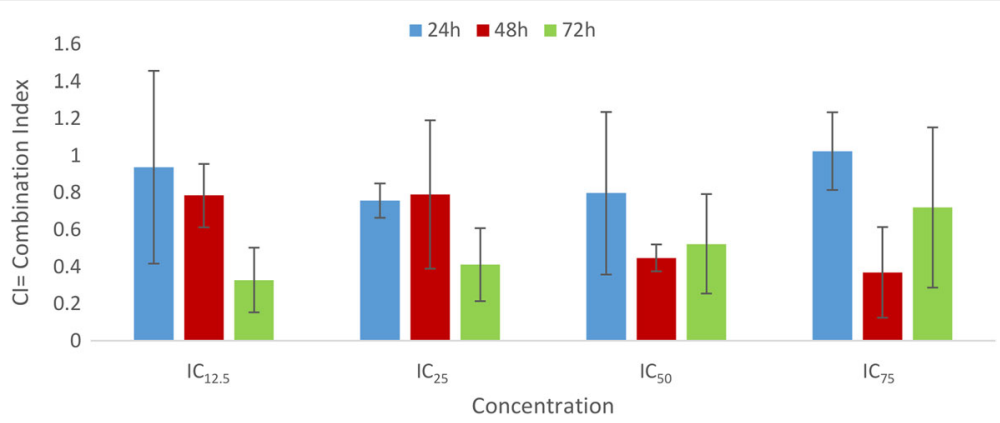

Fig. 9 Synergistic effect of drug combination. Hepg2 Cells were treated with FAA-doxorubicin in a serial dilution for 24, 48 and 72 h. Cl value was determined by Chou and Talalay method

A major part of apoptosis could be mediated by caspase-3, the promoter and the terminal effector in the apoptotic cascade [41, 51]. The findings confirmed that FAA is capable to induce caspase-dependent apoptosis in a time-dependent manner. Cleavage of caspase-3 led to exposure of phosphatidylserine on the external surface of the plasma membrane, measureable by annexin $\mathrm{V}$ binding [52]. These results are in agreement with the obtained effect of FAA on apoptosis (Fig. 5), where the cells exposed to the lower concentrations $\left(\mathrm{IC}_{25}\right.$ and $\mathrm{IC}_{50}$ ), showed an increase in caspase- 3 activity, whereas $\mathrm{IC}_{75}$ concentration of FAA ended up with necrosis which is annexin $\mathrm{V}-$. Moreover, the cleavage of caspase3 accelerates disassembly of cells, including DNA fragmentation, chromatin condensation, nuclear remodelling and membrane blebbing, as detected in the morphological study which suggested the caspase mediated apoptosis in HepG2 cells [53-55]. It has been reported that caspase-3 is essential for cleavage of multiple protein substrates, including $B c l-2$ [56]. The expression level of $B c l-2$ anti-apoptotic gene illustrated a significant downregulation after treatment with $\mathrm{IC}_{75}$ of FAA. Recent evidence suggests that $B c l-2$ also acts as a downstream death substrate of caspases and, thus, the caspase enzymes may be able to deactivate the $B c l-2$ antiapoptotic function and further enhance cell death, even when apoptosis is triggered via a non- $B c l-2$ dependent pathway. Although there is a feedback loop between $B c l-2$ and caspase, $B c l-2$ cannot always inhibit apoptosis, implying a subset of caspase activation that is likely to run through the death receptor pathway (not mitochondrial pathway) [57] that might occur in cells treated with lower concentrations. On the other hand, defective checkpoints are a feature of the majority of human cancers. Investigation into the expression level of $C d k 1$ revealed no significant change in this gene that was aligned with the result of the cell cycle (Fig. 4).

Deficiencies of checkpoint are mainly affected by mutations of $p 53$ in many cancers [58]. The functional $p 53$ encodes a nuclear phosphoprotein that regulates the synthesis of gene products involved in growth arrest, DNA repair, apoptosis and the inhibition of angiogenesis [59]. According to the present results, FAA is not enabled to increase the $p 53$ level, even the expression was significantly downregulated. It could be concluded that FAA induces apoptosis in a $p 53$ independent pathway. Although usual induction of cell death needs $p 53$, a reduced or delayed response can be activated via $p 53$-independent mechanisms following DNA damage. Cancer cells lacking $p 53$ required signalling for cell cycle arrest; the absence of this response activates caspase-3 and mitotic catastrophe [60].

Moreover, FAA synergistically increases the inhibitory effect of doxorubicin on HepG2 cell growth compared with individual doxorubicin treatments. Further, the $\mathrm{CI}$ analysis of FAA-doxorubicin revealed dramatic synergistic cytotoxic effects. The CI values obtained for cancer cells were $<1$, confirming a synergistic interaction between combined treatments. The importance of this finding lies in the fact that although doxorubicin is a potent anticancer agent, no one can deny its hazardous toxicity against normal cells, the harmful side effects on health and the development of primary and secondary drug resistance in cancer [61]. The mechanism of action is unclear and, possibly, multiple compounds in the herbal extract or multiple pathways are involved. For instance, mitochondrial permeability transition increased and caspase-3 activation was delayed in an exposure of doxorubicin, while oxidative DNA damage was induced by the $\mathrm{H}_{2} \mathrm{O}_{2}$ generation which caused a Doxinduced apoptotic pathway [62]. Doxorubicin is a DNAdamaging agent that causes early activation of $p 53$ in tumour cells. DNA damage, allowing $p 53$ to function as a transcription factor inducing apoptosis, decreased $\mathrm{Bcl}-2$ expression and increased cell permeability, and subsequently activated caspase- $3[63,64]$. On the other hand, sensitivity of doxorubicin-mediated apoptotic signalling may be enhanced by FAA through $\mathrm{Bcl}-2$ downregulation via caspase- 3 activation. Taken together, these findings indicate that a simultaneous blockade of different growth factor-driven signal-transduction pathways might lead to a more substantial antitumor effect [34]. 


\section{Conclusion}

Our findings support previous literature related to the pharmacological activities of different closely-related species of Allium. FAA demonstrated dose-dependent anti-proliferative properties in human hepatocarcinoma cells (HepG2) and pro-apoptotic properties independent of the p53 status of the cells. We also observed decreased expression of the anti-apoptotic protein $\mathrm{Bcl}-2$ in HepG2 which promotes the release of cytochrome $\mathrm{c}$ and further leads to activation of effector caspases-3. The presence of a sub-G0 population in cell cycle progression of HepG2 cells and cleaved caspase-3 staining suggests induction of apoptosis. These results have important clinical implications as they have commendable anti-proliferative activities against human hepatocarcinoma, without harming the normal cells, and it can be considered as an effective adjuvant therapeutic agent after clinical trials. However, further study of gene expression in time course and study of more genes related to apoptosis will improve our findings and give useful results to find a novel drug.

\section{Abbreviations}

AO: acridine orange; FAA: flower of Allium atroviolaceum; HCC: hepatocellular carcinoma; PI: propidium iodide

\section{Acknowledgement}

The authors thank Dr. Dehpour from the Azad University of Ghaemshahr, Iran and Dr.Eslami for identification the plant species and voucher number.

\section{Funding}

Not applicable.

\section{Availability of data and materials}

The datasets used and analysed during the current study available from the corresponding author on reasonable request.

\section{Authors' contributions}

The corresponding author, Pl, has generated the idea for the experiment and has critically examined and corrected the manuscript. SK, the first author has conducted the experimental work and written the manuscript. Other authors, HRA, ENM VR, GTFA and EE have helped during the experimental work and in the interpretation of the results. All authors read and approved the final manuscript.

\section{Competing interests}

The authors declare that they have no competing interests.

\section{Consent for publication}

Not applicable.

\section{Ethics approval and consent to participate}

Not applicable.

\author{
Author details \\ ${ }^{1}$ Department of Biomedical Science, Faculty of Medicine and Health \\ Sciences, Universiti Putra Malaysia, Serdang, Selangor 43400, Malaysia. \\ ${ }^{2}$ Department of Nutrition and Dietetics, Faculty of Medicine and Health \\ Sciences, Universiti Putra Malaysia, Serdang, Selangor 43400, Malaysia. \\ ${ }^{3}$ Malaysian Research Institute of Aging, Universiti Putra Malaysia, Serdang, \\ Selangor 43400, Malaysia.
}

Received: 13 August 2016 Accepted: 20 January 2017

Published online: 10 February 2017

\section{References}

1. Arıcan GO, Çakır O, Arıcan E, Kara T, Dağdeviren O, Arı S. Effects of Geven root extract on proliferation of HeLa cells and BCL2 gene expressions. Afr J Biotechnol. 2014;11:4296-304.

2. Papadopoulos El, Yousef GM, Scorilas A. Cytotoxic activity of sunitinib and everolimus in Caki-1 renal cancer cells is accompanied by modulations in the expression of apoptosis-related microRNA clusters and BCL2 family genes. Biomed Pharmacother. 2015;70:33-40.

3. Dai ZJ, Gao J, Li ZF, Ji ZZ, Kang HF, Guan HT, et al. In vitro and in vivo antitumor activity of Scutellaria barbate extract on murine liver cancer. Molecules. 2011;16:4389-400.

4. Nair SV, Hettihewa M, Rupasinghe HP. Apoptotic and inhibitory effects on cell proliferation of Hepatocelular carcinoma HepG2 cells by methanol leaf extract of Costus speciosus. BioMed research international. 2014; doi: 10.1155/2014/637098.

5. Gandhi S, Khubchandani S, Iyer R. Quality of life and hepatocellular carcinoma. J Gastrointestl Oncol. 2014;5:296-317.

6. Qiao Y, Xiang Q, Yuan L, Xu L, Liu Z, Liu X. Herbacetin induces apoptosis in HepG2 cells: Involvements of ROS and PI3K/Akt pathway. Food Chem Toxicol. 2013;51:426-33.

7. Liu AM, Poon RT, Luk JM. MicroRNA-375 targets Hippo-signaling effector YAP in liver cancer and inhibits tumor properties. Biochem Biophys Res Community. 2010;394:623-7.

8. Chuang SC, La Vecchia C, Boffetta P. Liver cancer: descriptive epidemiology and risk factors other than HBV and HCV infection. Cancer Lett. 2009;286:914.

9. Kalaiselvi M, Narmadha R, Ragavendran P, Raj A, Sophia D, Kumar GR, Kalaivani K. In vivo simulated in vitro model of Jasminum sambac (Linn.) using mammalian liver slice technique. Asian Pac J Trop Biomed. 2011;1:216-9.

10. Fathy SA, Singab ANB, Agwa SA, El Hamid DMA, Zahra FA, El Moneim SMA. The antiproliferative effect of mulberry (Morus alba L.) plant on hepatocarcinoma cell line HepG2. Egypt J Med Hum Genet. 2013;14:375-82.

11. Guo J, Wang MH. Extract of Ulmus davidiana Planch barks induced apoptosis in human hepatoma cell line HepG2. Exp Clin Sci. 2009;8:130-7.

12. Samarakoon SR, Thabrew I, Galhena PB, Tennekoon KH. Effect of standardized decoction of Nigella sativa seed, Hemidesmus indicus root and Smilax glabra rhizome on the expression of p53 and p21 genes in human hepatoma cells (HepG2) and mouse liver with chemically-induced hepatocarcinogenesis. Trop J Pharm Res. 2012;11:51-61.

13. Shoeb M. Anticancer agents from medicinal plants. Bangladesh J Pharmacol. 2006;1:35-41.

14. Jain R, Jain SK. Screening of in vitro cytotoxic activity of some medicinal plants used traditionally to treat cancer in Chhattisgarh state, India. Asian Pac J Trop Biomed. 2011;1:47-150.

15. Bhadury P, Mohammad BT, Wright PC. The current status of natural products from fungi and their potential as anti-effective agents. J India Microb Biotechnol. 2006;33:325-37.

16. Sengupta A, Ghosh S, Bhattacharjee S. Allium vegetables in cancer prevention: an overview. Asian Pac J Cancer Prev. 2004;5:237-45.

17. Mohammadi-Motlagh HR, Mostafaie A, Mansouri K. Anticancer and anti-inflammatory activities of shallot. Arch Med Sci. 2011;7:38-44.

18. Zolfaghari B, Barile E, Capasso R, Izzo AA, Sajjadi SE, Lanzotti V. The Sapogenin atroviolacegenin and its diglycoside atroviolaceoside from Allium atroviolaceum. J Nat Prod. 2006;69:191-5.

19. Podolak I, Galanty A, Sobolewska D. Saponins as cytotoxic agents: a review. Phytochem Rev. 2010;9:425-74

20. Dehpour AA, Babakhani B, Khazaei S, Asadi M. Chemical composition of essential oil and antibacterial activity of extracts from flower of Allium atroviolaceum. J Med Plants Res. 2011;5:3667-72.

21. Powolny AA, Singh SV. Multitargeted prevention and therapy of cancer by diallyl trisulfide and related Allium vegetable-derived organosulfur compounds. Cancer Lett. 2008;269:305-14.

22. Tepe B, Sokmen M, Akpulat HA, Sokmen A. In vitro antioxidant activities of the methanol extracts of five Allium species from Turkey. Food Chem. 2005:92:89-92.

23. Bakar MFA, Mohamad M, Rahmat A, Burr SA, Fry JR. Cytotoxicity, cell cycle arrest, and apoptosis in breast cancer cell lines exposed to an extract of the seed kernel of Mangifera pajang (bambangan). Food Chem Toxicol. 2010;48:1688-97.

24. Syed Abdul Rahman SN, Abdul Wahab N, Abd Malek SN. In vitro morphological assessment of apoptosis induced by antiproliferative constituents from the rhizomes of Curcuma zedoaria. Evid Based Complement Alternat Med. 2013;2013:257108. 
25. Yan X, Doffek K, Yin C, Krein M, Phillips M, Sugg SL, et al. Annexin-V promotes anti-tumor immunity and inhibits neuroblastoma growth in vivo. Cancer Immunol Immunother. 2012;61:1917-27.

26. Kanagesan S, Hashim M, Tamilselvan S, Alitheen NB, Ismail I, Bahmanrokh G. "Cytotoxic Effect of Nanocrystalline MgFe2O4 Particles for Cancer Cure". J Nanomaterials. 2013;2013:8. doi:10.1155/2013/865024.

27. Wong FC, Woo CC, Hsu A, Tan BKH. The anti-cancer activities of Vernonia amygdalina extract in human breast cancer cell lines are mediated through caspase-dependent and p53-independent pathways. PLoS One. 2013;8:78021.

28. Mahassni SH, Al-Reemi RM. Apoptosis and necrosis of human breast cancer cells by an aqueous extract of garden cress (Lepidium sativum) seeds. Saudi J Biol Sci. 2013;20:131-9.

29. Chen L, Zhang X, Chen J, Zhang X, Fan H, Li S, Xie P. NF-kB plays a key role in microcystin-RR-induced HeLa cell proliferation and apoptosis. Toxicon. 2014:87:120-30

30. Chang CC, Liang YC, Klutz A, Hsu Cl, Lin CF, Mold DE, et al. Reversal of multidrug resistance by two nordihydroguaiaretic acid derivatives, $\mathrm{M}_{4} \mathrm{~N}$ and maltose- $\mathrm{M}_{3} \mathrm{~N}$, and their use in combination with doxorubicin or paclitaxel. Cancer Chemother Pharmacol. 2006;58:640-53.

31. Khazaei S, Esa NM, Ramachandran V, Hamid RA, Pandurangan AK, Etemad A and Ismail P. In vitro Antiproliferative and Apoptosis Inducing Effect of Allium atroviolaceum Bulb Extract on Breast, Cervical, and Liver Cancer Cells. Front Pharmacol. 2017; 8:5. doi:10.3389/fphar.2017.00005.

32. Elmore S. Apoptosis: a review of programmed cell death. Toxicol Pathol. 2007;35:495-516

33. Taparia SS, Khanna A. Procyanidin-rich extract of natural cocoa powder causes ROS-mediated caspase-3 dependent apoptosis and reduction of pro-MMP-2 in epithelial ovarian carcinoma cell lines. Biomed Pharmacotherapy. 2016;83:130-40.

34. Normanno N, Campiglio M, De Luca A, Somenzi G, Maiello M, Ciardiello F, et al. Cooperative inhibitory effect of ZD1839 (Iressa) in combination with trastuzumab (Herceptin) on human breast cancer cell growth. Ann Oncol. 2002;13:65-72.

35. Wu SJ, Ng LT, Chen CH, Lin DL, Wang SS, Lin CC. Antihepatoma activity of Physalis angulata and P. peruviana extracts and their effects on apoptosis in human HepG2 cells. Life Sci. 2004;74:2061-73.

36. Prakash OM, Kumar A, Kumar P. Anticancer potential of plants and natural products: A review. Am J Pharmacol Sci. 2013;1:104-15.

37. Solyanik Gl. Multifactorial nature of tumor drug resistance. Exp Oncol. 2010;32:181-5

38. Cariddi L, Escobar F, Sabini C, Torres C, Reinoso E, Cristofolini A, et al. Apoptosis and mutagenicity induction by a characterized aqueous extract of Baccharis articulata (Lam.) Pers. (Asteraceae) on normal cells. Food Chem Toxicol. 2012;50:155-61.

39. Stankovic MS, Curcic MG, Zizic JB, Topuzovic MD, Solujic SR, Markovic SD. Teucrium plant species as natural sources of novel anticancer compounds: antiproliferative, proapoptotic and antioxidant properties. Int J Mol Sci. 2011;12:4190-205.

40. Alshatwi AA, Periasamy VS, Athinarayanan J, Elango R. Synergistic anticancer activity of dietary tea polyphenols and bleomycin hydrochloride in human cervical cancer cell: Caspase-dependent and independent apoptotic pathways. Chem Biol Interact. 2016;247:1-10.

41. Wahab A, Ibrahim S, Abdul AB, Alzubairi AS, Mohamed Elhassan M, Mohan S In vitro ultramorphological assessment of apoptosis induced by zerumbone on (HeLa). Biomed Res Int. 2009. http://dx.doi.org/10.1155/2009/769568.

42. Bowen ID, Bowen SM, Jones AH. Mitosis and apoptosis: Matters of life and death. London: Chapman and Hall; 1998.

43. Barros LF, Kanaseki T, Sabirov R, Morishima S, Castro J, Bittner CX, et al. Apoptotic and necrotic blebs in epithelial cells display similar neck diameters but different kinase dependency. Cell Death Differ. 2003;10:687-97.

44. Collins JA, Schandl CA, Young KK, Vesely J, Willingham MC. Major DNA fragmentation is a late event in apoptosis. J Histochem Cytochem. 1997;45:923-34.

45. Han YH, Park WH. Growth inhibition in antimycinA treated-lung cancer Calu-6 cells via inducing a G1 phase arrest and apoptosis. Lung Cancer. 2009;65:150-60.

46. Ng WK, Yazan LS, Ismail M. Thymoquinone from Nigella sativa was more potent than cisplatin in eliminating of SiHa cells via apoptosis with downregulation of BCL2 protein. Toxicol in Vitro. 2011;25:1392-8.

47. Brauchle E, Thude S, Brucker SY, Schenke-Layland K. Cell death stages in single apoptotic and necrotic cells monitored by Raman microspectroscopy. Sci Rep. 2014. doi:10.1038/srep04698.
48. Dartsch DC, Schaefer A, Boldt S, Kolch W, Marquardt H. Comparison of anthracyclineinduced death of human leukemia cells: programmed cell death versus necrosis. Apoptosis. 2002;7:537-48.

49. Patel VA, Longacre A, Hsiao K, Fan H, Meng F, Mitchell JE, et al. Apoptotic cells, at all stages of the death process, Trigger characteristic signaling events that are divergent from and dominant over those triggered by necrotic cells implications for the delayed clearance model of autoimmunity. J Biol Chem. 2006;281:4663-70.

50. Stepanek O, Brdicka T, Angelisova P, Horvath O, Spicka J, Stockbauer P, et al. Interaction of late apoptotic and necrotic cells with vitronectin. PLoS One. 2011;6:5.

51. Cabrera M, Gomez N, Lenicov FR, Echeverría E, Shayo C, Moglioni A, et al. G2/M cell cycle arrest and tumor selective apoptosis of acute leukemia cells by a promising benzophenone thiosemicarbazone compound. PLoS One. 2015;10:9.

52. Sundquist T, Moravec R, Niles A, O'Brien M, Riss T. Timing your apoptosis assays. Cell Notes. 2006;16:18-21.

53. George BP, Abrahamse H, Parimelazhagan T. Caspase dependent apoptotic activity of Rubus fairholmianus Gard. on MCF-7 human breast cancer cell lines. J Appl Biomed. 2016. doi:10.1016/j.jab.2016.02.001.

54. Sreelatha S, Jeyachitra A, Padma PR. Antiproliferation and induction of apoptosis by Moringa oleifera leaf extract on human cancer cells. Food Chem Toxicol. 2011;49:1270-5.

55. Pourhassanali N, Roshan-Milani S, Kheradmand F, Motazakker M, Bagheri M, Saboory E. Zinc attenuates ethanol-induced Sertoli cell toxicity and apoptosis through caspase-3 mediated pathways. Reprod Toxicol. 2016;61:97-103.

56. Xue LY, Chiu SM, Oleinick NL. Photodynamic therapy-induced death of MCF-7 human breast cancer cells: a role for caspase-3 in the late steps of apoptosis but not for the critical lethal event. Exp Cell Res. 2001;263:145-55.

57. Yang B, Johnson TS, Thomas GL, Watson PF, Wagner B, Furness PN, El Nahas AM. A shift in the Bax/BCl-2 balance may activate caspase-3 and modulate apoptosis in experimental glomerulonephritis. Kidney Int. 2002;62:1301-13.

58. Chung JH, Bunz F. Cdk2 Is required for p53-independent G 2/M checkpoint control. PLoS Genet. 2010;6:2

59. Kralj M, Husnjak K, Körbler T, Pavelić J. Endogenous p21WAF1/CIP1 status predicts the response of human tumor cells to wild-type p53 and p21WAF1/CIP1 overexpression. Cancer Gene Ther. 2003:10:457-67.

60. McNamee LM, Brodsky MH. p53-independent apoptosis limits DNA damage-induced aneuploidy. Genetics. 2009:182:423-35.

61. Pinmai K, Chunlaratthanabhorn S, Ngamkitidechakul C, Soonthornchareon N, Hahnvajanawong C. Synergistic growth inhibitory effects of Phyllanthus emblica and Terminalia bellerica extracts with conventional cytotoxic agents: doxorubicin and cisplatin against human hepatocellular carcinoma and lung cancer cells. World J Gastroenterol. 2008;14:1491-7.

62. Mizutani H, Tada-Oikawa S, Hiraku Y, Kojima M, Kawanishi S. Mechanism of apoptosis induced by doxorubicin through the generation of hydrogen peroxide. Life Sci. 2005;76:1439-53.

63. Lee JS, Hong EK. Agaricus blazei Murill enhances doxorubicin-induced apoptosis in human hepatocellular carcinoma cells by NFkB-mediated increase of intracellular doxorubicin accumulation. Int J Oncol. 2011;38:401-8.

64 Wang S, Konorev EA, Kotamraju S, Joseph J, Kalivendi S, Kalyanaraman B. Doxorubicin Induces Apoptosis in Normal and Tumor Cells via Distinctly Different Mechanisms: INTERMEDIACY OF H2O2- AND p53-DEPENDENT PATHWAYS. J Biol Chem. 2004;279(24):25535-43.

\section{Submit your next manuscript to BioMed Central and we will help you at every step:}

- We accept pre-submission inquiries

- Our selector tool helps you to find the most relevant journal

- We provide round the clock customer support

- Convenient online submission

- Thorough peer review

- Inclusion in PubMed and all major indexing services

- Maximum visibility for your research

Submit your manuscript at www.biomedcentral.com/submit 